Medical Informatics \& Decision Making

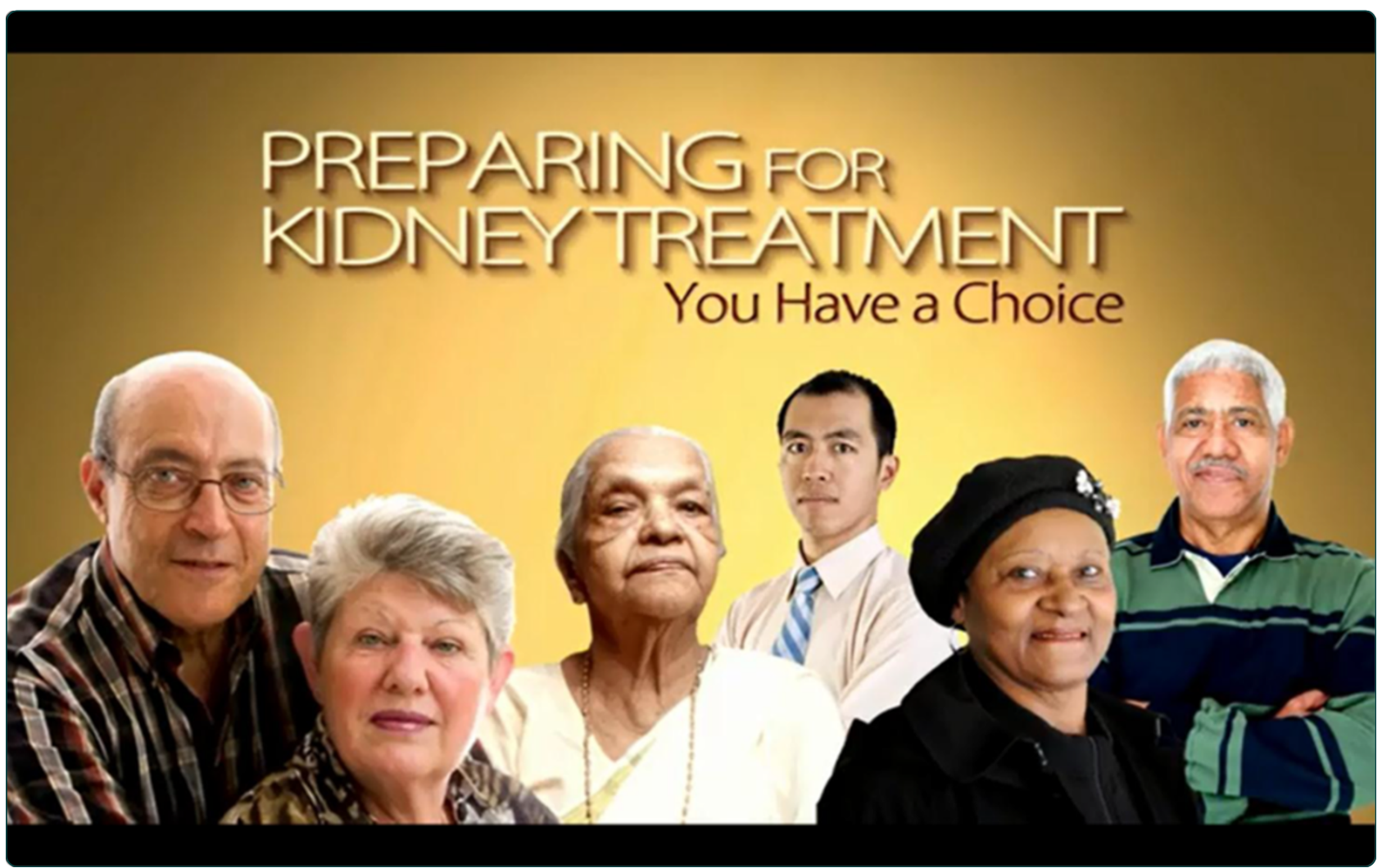

Development of a decision aid to inform patients' and families' renal replacement therapy selection decisions

Ameling et al. 


\title{
Development of a decision aid to inform patients' and families' renal replacement therapy selection decisions
}

\author{
Jessica M Ameling 1,2, Priscilla Auguste 1,2, Patti L Ephraim 1,3, LaPricia Lewis-Boyer ${ }^{1,2}$, Nicole DePasquale 1,2, \\ Raquel C Greer ${ }^{1,2}$, Deidra C Crews ${ }^{1,4}$, Neil R Powe ${ }^{5}$, Hamid Rabb ${ }^{4}$ and L Ebony Boulware ${ }^{1,2,3^{*}}$
}

\begin{abstract}
Background: Few educational resources have been developed to inform patients' renal replacement therapy (RRT) selection decisions. Patients progressing toward end stage renal disease (ESRD) must decide among multiple treatment options with varying characteristics. Complex information about treatments must be adequately conveyed to patients with different educational backgrounds and informational needs. Decisions about treatment options also require family input, as families often participate in patients' treatment and support patients' decisions. We describe the development, design, and preliminary evaluation of an informational, evidence-based, and patient-and family-centered decision aid for patients with ESRD and varying levels of health literacy, health numeracy, and cognitive function.
\end{abstract}

Methods: We designed a decision aid comprising a complementary video and informational handbook. We based our development process on data previously obtained from qualitative focus groups and systematic literature reviews. We simultaneously developed the video and handbook in "stages." For the video, stages included (1) directed interviews with culturally appropriate patients and families and preliminary script development, (2) video production, and (3) screening the video with patients and their families. For the handbook, stages comprised (1) preliminary content design, (2) a mixed-methods pilot study among diverse patients to assess comprehension of handbook material, and (3) screening the handbook with patients and their families.

Results: The video and handbook both addressed potential benefits and trade-offs of treatment selections. The 50-minute video consisted of demographically diverse patients and their families describing their positive and negative experiences with selecting a treatment option. The video also incorporated health professionals' testimonials regarding various considerations that might influence patients' and families' treatment selections. The handbook was comprised of written words, pictures of patients and health care providers, and diagrams describing the findings and quality of scientific studies comparing treatments. The handbook text was written at a $4^{\text {th }}$ to $6^{\text {th }}$ grade reading level. Pilot study results demonstrated that a majority of patients could understand information presented in the handbook. Patient and families screening the nearly completed video and handbook reviewed the materials favorably.

Conclusions: This rigorously designed decision aid may help patients and families make informed decisions about their treatment options for RRT that are well aligned with their values.

Keywords: Kidney disease, Decision aid, Literacy, Numeracy, Cognitive function

\footnotetext{
* Correspondence: Iboulwa@jhmi.edu

'Welch Center for Prevention, Epidemiology and Clinical Research, Johns

Hopkins Medical Institutions, Baltimore, Maryland, USA

${ }^{2}$ Division of General Internal Medicine, Johns Hopkins University School of

Medicine, Baltimore, Maryland, USA

Full list of author information is available at the end of the article
} 


\section{Background}

Patients whose advanced chronic kidney disease (CKD) is approaching end-stage renal disease (ESRD), or complete kidney failure, face complex medical decision-making regarding the type of medical therapy they wish to pursue. Choices for treating ESRD are numerous and include renal replacement therapies (RRTs) such as hemodialysis delivered in a dialysis center three times per week, home care dialysis (including peritoneal dialysis and home hemodialysis, which patients administer to themselves daily), and living or deceased kidney transplantation. Patients may also choose to forgo RRT and instead opt for conservative medical therapy (i.e., ongoing medical care with their nephrologists to optimize health without dialysis or kidney transplantation). Each treatment option has different advantages, limitations, and implications for survival, quality of life, financial stability, general health status, and how patients experience their daily lives [1-3]. For instance, home dialysis therapies require patients' substantial self-care and may afford patients more control over their daily schedules, while in-center hemodialysis requires less self-management but more frequent interface with medical professionals and may offer patients less autonomy [4]. Patients' families are also impacted by RRT decisions, as they often play substantial caregiver roles [5].

Despite patients' critical need to understand the characteristics of various RRTs to inform their treatment decisions, many patients report having little to no general awareness of what types of treatment options exist for ESRD and many have little knowledge of treatment risks and benefits prior to their initiation of RRT [2,5-9]. Patients' poor access to adequate education about treatments has been linked to their abrupt initiation of dialysis and their suboptimal access to other forms of RRT, $[10,11]$ such as kidney transplantation, which is associated with improved clinical outcomes [6,12-14]. A substantial proportion of patients with ESRD are elderly and may have low educational attainment, poor health literacy and numeracy, and cognitive decline associated with their advancing kidney disease, heightening the challenges of educating patients about their RRT choices [15-18].

Comprehensive decision aids are needed to help patients with kidney disease and their families make informed RRT selection decisions aligned with their personal values. This paper describes our development of a patient-and-family centered decision aid to inform RRT selection decisions.

\section{Methods}

Overarching goals, decision Aid content, and approach to decision Aid design

Goals

We sought to develop a patient-and-family centered decision aid (handbook and video) to help patients and families choose among numerous RRT options. We sought to ensure that the decision aid could be understood by patients with a range of health literacy, health numeracy, and cognitive needs. We used the 2006 International Patient Decision Aids Standards (IPDAS) to guide our development process [19]. All aspects of the decision aid design, including the collection of primary patient and family data to inform development, were approved by the Johns Hopkins Medicine Institutional Review Board.

\section{Decision aid content}

We intended for the decision aid to address both positive and negative features of treatment options that patients (who had previously experienced treatments) and their family members felt others making RRT decisions should know about. We identified content to include via: (1) our own conduct of 20 focus groups of patients and families identifying information they felt should be included in decision aids guiding others' RRT selections (described elsewhere) [5] as well as our selective review of qualitative studies published by other investigators, [2,3,20] and (2) our conduct of rigorous systematic literature reviews describing findings of scientific studies comparing outcomes among patients selecting different RRTs (described elsewhere) [21-24]. Our decision aid focused on seven key content areas or "concerns" about treatments, including how treatments might affect patients': (1) morbidity and mortality ("health problems"), (2) autonomy ("doing things"), (3) treatment delivery ("how treatment works"), (4) symptoms ("symptoms"), (5) relationships ("relationships"), (6) psychological well being ("feelings"), and (7) finances ("money matters") (Table 1).

\section{Approach to designing the decision aid}

We intended for the video and handbook to present complementary subjective (in video) and evidence-based (in handbook) information to a diverse English-speaking audience. We developed the video and handbook simultaneously in three "stages" (Figure 1). We engaged a multidisciplinary group of experts throughout the development process, which included clinical experts (physicians, social workers), an adult health education specialist, a patient advocacy specialist, a video scriptwriter, and a medical illustrator.

\section{Methods: developing the video}

We intended to provide patients and their families with specific testimonials from others who had already made treatment decisions. We attempted to ensure these testimonials addressed as many of the seven previously identified "concerns" as possible. When patients or families did not address "concerns" in their testimonials, or if deemed appropriate, we incorporated testimonials from health care 
Table 1 Topics addressed in the decision aid

\begin{tabular}{|c|c|c|c|}
\hline Concern & Factor & Video & Handbook \\
\hline $\begin{array}{l}\text { Morbidity/ } \\
\text { Mortality }\end{array}$ & Living longer & & \\
\hline \multirow{4}{*}{$\begin{array}{l}\text { ("Health } \\
\text { Problems") }\end{array}$} & Infections & $\cdot$ & • \\
\hline & Complications with surgery & $\cdot$ & $\cdot$ \\
\hline & $\begin{array}{l}\text { Making frequent trips to the } \\
\text { doctor }\end{array}$ & $\cdot$ & \\
\hline & Going to the hospital & $\cdot$ & \\
\hline \multirow[t]{20}{*}{$\begin{array}{l}\text { Autonomy ("Doing } \\
\text { Things") }\end{array}$} & $\begin{array}{l}\text { Doing things I want to do } \\
\text { when I want to do them }\end{array}$ & $\cdot$ & $\cdot$ \\
\hline & Doing my usual activities & $\cdot$ & $\cdot$ \\
\hline & $\begin{array}{l}\text { Freedom and control over } \\
\text { my life }\end{array}$ & $\cdot$ & . \\
\hline & What I can eat or drink & $\cdot$ & \\
\hline & $\begin{array}{l}\text { Control over my treatment } \\
\text { schedule }\end{array}$ & $\cdot$ & \\
\hline & Going places by myself & $\cdot$ & \\
\hline & My quality of life & $\cdot$ & $\cdot$ \\
\hline & My social life & $\cdot$ & $\cdot$ \\
\hline & $\begin{array}{l}\text { Ability to do things in my } \\
\text { free time }\end{array}$ & $\cdot$ & $\cdot$ \\
\hline & How much free time I have & $\cdot$ & $\cdot$ \\
\hline & How I feel about traveling & $\cdot$ & $\cdot$ \\
\hline & Ability to go to work & $\cdot$ & $\cdot$ \\
\hline & What I can do at work & & $\cdot$ \\
\hline & How I feel about my work & $\cdot$ & $\cdot$ \\
\hline & My job and money & $\cdot$ & $\cdot$ \\
\hline & How free I feel to do things & & $\cdot$ \\
\hline & Ability to do day-to-day tasks & & • \\
\hline & My ability to get around & & $\cdot$ \\
\hline & $\begin{array}{l}\text { How I feel about getting } \\
\text { around }\end{array}$ & & . \\
\hline & Caring for myself & $\cdot$ & $\cdot$ \\
\hline \multirow{8}{*}{$\begin{array}{l}\text { Treatment } \\
\text { Delivery (“How } \\
\text { Treatment Works") }\end{array}$} & $\begin{array}{l}\text { Dialysis/transplant going as } \\
\text { expected }\end{array}$ & $\cdot$ & \\
\hline & Pills I have to take & $\cdot$ & \\
\hline & Providing my own treatment & $\cdot$ & \\
\hline & $\begin{array}{l}\text { Ordering/storing supplies at } \\
\text { home }\end{array}$ & $\cdot$ & \\
\hline & Fistula or catheter problems & $\cdot$ & \\
\hline & Finding a living donor & $\cdot$ & \\
\hline & $\begin{array}{l}\text { Surgery for fistulas or } \\
\text { catheters }\end{array}$ & $\cdot$ & \\
\hline & $\begin{array}{l}\text { Blood tests, } x \text {-rays, and } \\
\text { doctor visits }\end{array}$ & $\cdot$ & \\
\hline \multirow{6}{*}{$\begin{array}{l}\text { Symptoms } \\
\text { ("Symptoms") }\end{array}$} & Feeling tired & $\cdot$ & $\cdot$ \\
\hline & Thinking clearly & $\cdot$ & $\cdot$ \\
\hline & My memory & $\cdot$ & $\cdot$ \\
\hline & My attention & $\cdot$ & $\cdot$ \\
\hline & How well I can learn & & $\cdot$ \\
\hline & Itching, cramping, or aching & $\cdot$ & - \\
\hline
\end{tabular}

Table 1 Topics addressed in the decision aid (Continued)

\begin{tabular}{|c|c|c|c|}
\hline & Gaining weight & · & \\
\hline & Pain & • & $\cdot$ \\
\hline & Joint pain & & . \\
\hline & How healthy my body feels & & $\cdot$ \\
\hline & My energy & · & . \\
\hline & Cramps & . & . \\
\hline & Stomach problems & • & • \\
\hline & Bowel problems & $\cdot$ & $\cdot$ \\
\hline & Cough & & $\cdot$ \\
\hline & Trouble breathing & $\cdot$ & $\cdot$ \\
\hline & Skin problems & & $\cdot$ \\
\hline & Dry skin & & • \\
\hline & Changes in skin color & & $\cdot$ \\
\hline & How well I sleep & & . \\
\hline & How I feel about my looks & • & • \\
\hline $\begin{array}{l}\text { Relationships } \\
\text { ("Relationships") }\end{array}$ & $\begin{array}{l}\text { Family and friends need to } \\
\text { help }\end{array}$ & $\cdot$ & \\
\hline & Making new friends & . & \\
\hline & $\begin{array}{l}\text { Having and enjoying sexual } \\
\text { relations }\end{array}$ & • & $\cdot$ \\
\hline & Sex drive & • & • \\
\hline & Orgasm problems & & . \\
\hline & Pain with sex & & • \\
\hline & Erection problems (Men) & • & $\cdot$ \\
\hline & Ejaculation problems (Men) & & • \\
\hline & Chances of having sex (Men) & & $\cdot$ \\
\hline & $\begin{array}{l}\text { Trouble getting excited } \\
\text { (Women) }\end{array}$ & - & • \\
\hline & Vaginal dryness (Women) & • & • \\
\hline $\begin{array}{l}\text { Psychological } \\
\text { ("Feelings") }\end{array}$ & $\begin{array}{l}\text { Feeling sad, anxious, or } \\
\text { stressed out }\end{array}$ & - & • \\
\hline & Chances of being depressed & • & • \\
\hline & My nerves & • & • \\
\hline & My well-being & • & • \\
\hline & My emotions & . & . \\
\hline & My mood & • & • \\
\hline & $\begin{array}{l}\text { How happy I am with my } \\
\text { life }\end{array}$ & - & . \\
\hline $\begin{array}{l}\text { Finance ("Money } \\
\text { Matters") }\end{array}$ & $\begin{array}{l}\text { Money spent from own } \\
\text { pocket }\end{array}$ & • & \\
\hline
\end{tabular}

professionals who could provide additional views regarding common patient experiences relevant to the "concerns."

Video development stage 1: selecting patients and families for the video, writing the script

Engaging a scriptwriter We engaged a professional video scriptwriter with experience creating medical education videos. The scriptwriter reviewed findings from our foundational research and worked with our 
investigative team to develop questions designed to elicit positive and negative viewpoints from patients and families about their chosen RRTs.

Selecting patients and families and writing the script. We worked with local nephrologists in Baltimore, MD to identify a diverse group of patients who might potentially participate in the video. We asked nephrologists to select patients receiving different forms of RRT with specific demographic characteristics (e.g., minority female who received a transplant) to ensure diversity. The scriptwriter conducted 90 to 120 minute directed interviews with patients and family members and recorded the content of interviews for review.

The scriptwriter then drafted a script by incorporating views she obtained from patients and families. In our previously conducted focus groups, patients and families identified health care professionals they thought would be appropriate to address various "concerns." For example, patients and family members felt physicians would be appropriate for discussions about the health risks and benefits associated with treatment selections, while social workers would be more appropriate for discussing financial considerations. Our investigative team reviewed the script and refined it to ensure all seven "concerns" were adequately addressed by either patients and families or health professionals (which included a transplant nephrologist, transplant social worker, general nephrologist, and dialysis social worker).

We also ensured that the video addressed complementary information to the handbook. Because the handbook summarized findings from scientific studies about the various RRT options (e.g., differences of health risks associated with different therapies), we did not include this type of quantitative information in the video (Table 1).

\section{Video development stage 2: producing the video}

Filming and producing the video A professional video production crew filmed patients and family members in their homes during scheduled visits. To obtain testimonials on camera, an investigative team member interviewed them using the same questions the scriptwriter asked during initial directed interviews. The crew filmed health care personnel in a studio. An investigative team member asked health care providers questions to address issues that patient testimonials did not already address. After completing video filming and editing, we iteratively refined the video, focusing on decreasing length and improving clarity, consistency, and accuracy.

\section{Video development stage 3: video screening and final edits}

Screening groups Prior to final editing, we recruited five patients receiving different RRTs from two local, academically affiliated nephrology practices in Baltimore, $\mathrm{MD}$ and seven of the patients' family members to screen the video and provide their qualitative feedback during a two hour group meeting led by a trained moderator. The moderator elicited participants' initial impressions of the video as well as feedback regarding length, amount of information presented, understandability, the balance in presentation of positive and negative aspects of the treatments, and areas for improvement. We audio-recorded and transcribed screening group discussions and we incorporated screening groups' feedback in our final iterations.

\section{Methods: developing the handbook}

The handbook complemented the video (Table 1) and summarized findings from scientific studies about differences in patient-reported and clinical outcomes among patients receiving different treatment options (in-center hemodialysis, peritoneal dialysis, kidney transplantation, and medical therapy with no dialysis or transplantation). We also provided information about the methodological quality of scientific studies. The handbook focused on the same seven "concerns" highlighted in the video.

\section{Handbook development stage 1: preliminary handbook content design by our investigative team}

We worked with specialists in medical illustration, adult education, health communications, and in adapting materials for low literacy readers to develop the handbook. We created several mock designs for presenting information before conducting the pilot study.

\section{Handbook development stage 2: mixed-methods pilot study to guide iterative design}

During early handbook development, we confronted three main challenges, including (1) presenting information about differences in multiple treatment types, (2) presenting information quantifying the magnitude and direction of scientific findings that did not incorporate risk probabilities and could not be described using standard methods (e.g. pictograms or bar graphs), [25] and (3) communicating information to patients about the quality of scientific evidence available to inform a decision. [26] To help address these challenges, we performed a pilot study among patients with kidney disease to obtain their input on the clarity of information we presented in various handbook iterations.

Pilot study goals, setting, and participants In two study "phases," we recruited a total of 48 English-speaking patients from two local nephrology practices in the Baltimore, MD metropolitan area to obtain qualitative feedback on handbook material (Phase 1 and 2) and quantitatively test patients' comprehension of handbook 
- Conducted 20 focus groups, a selective review of qualitative studies by other investigators, and systematic literature reviews to identify patients' and families' concerns and informational needs regarding renal replacement therapy

\begin{tabular}{|c|c|}
\hline Video Development (17 total iterations) & Handbook Development (26 total iterations) \\
\hline $\begin{array}{l}\text { Stage } 1 \text { (26 months, } 11 \text { script iterations) } \\
\text { Multidisciplinary team of experts developed a } \\
\text { preliminary structure for the video and handbook } \\
\text { to ensure their complementary nature and } \\
\text { attention to seven key content areas } \\
\text { - Selected a diverse group of patients receiving } \\
\text { different renal replacement therapies, their } \\
\text { family members, and health care professionals } \\
\text { for potential participation in the video } \\
\text { Conducted directed interviews to acquire patient } \\
\text { and family member testimonials regarding their } \\
\text { treatment experiences and draft an initial video } \\
\text { script }\end{array}$ & $\begin{array}{l}\text { Stage 1 (12 months, } 3 \text { iterations) } \\
\text { - } \begin{array}{l}\text { Multidisciplinary team of experts developed a } \\
\text { preliminary structure for the video and handbook to } \\
\text { ensure their complementary nature and attention to } \\
\text { seven key content areas }\end{array} \\
\text { - Worked with a medical illustrator, adult education } \\
\text { specialist, communications specialist, and a literacy } \\
\text { expert to establish a preliminary standard format for } \\
\text { presenting scientific information to patients }\end{array}$ \\
\hline $\begin{array}{l}\text { Stage } 2 \text { (12 months, } 3 \text { video iterations) } \\
\text { - Filmed patient, family member, and provider } \\
\text { testimonials addressing seven key content areas } \\
\text { - Edited the video } \\
\text { - Produced a video draft suitable for screening }\end{array}$ & $\begin{array}{l}\text { Stage } 2 \text { (15 months, } 22 \text { iterations ) } \\
\text { - Performed a two-phase mixed-methods study } \\
\text { Phase 1, } 16 \text { iterations } \\
\text { - Conducted cognitive interviews with } 12 \text { patients to } \\
\text { obtain critical feedback regarding the } \\
\text { understandability of information presented and } \\
\text { identify areas for improvement } \\
\begin{array}{l}\text { Phase 2, } 6 \text { iterations } \\
\text { - Performed an additional } 36 \text { cognitive interviews to } \\
\text { obtain quantitative measures of comprehension and } \\
\text { qualitative input on the presentation of information }\end{array}\end{array}$ \\
\hline $\begin{array}{l}\text { Stage } 3 \text { (4 months, } 3 \text { video iterations) } \\
\text { - Screened a video draft to obtain qualitative } \\
\text { feedback from patients and family members (12 } \\
\text { participants total) }\end{array}$ & $\begin{array}{l}\text { Stage } 3 \text { (2 months, } 1 \text { iteration) } \\
\text { Screened a handbook draft to obtain qualitative } \\
\text { feedback from patients and family members (12 } \\
\text { participants total) }\end{array}$ \\
\hline - Produced a final version of the video & \\
\hline
\end{tabular}

Figure 1 Decision aid development process.

material (Phase 2 only) during the iterative design process. For both phases, we asked nephrologists to identify patients either on dialysis or with progressive CKD ("PreESRD," defined as estimated glomerular filtration rate of less than $30 \mathrm{ml} / \mathrm{min} / 1.73 \mathrm{~m}^{2}$ ) but not yet receiving dialysis or a kidney transplant. We then approached patients to assess their interest in participating in cognitive interviews.

Phase 1 cognitive interviews During study Phase 1, we performed cognitive interviews with 12 patients with kidney disease to obtain feedback regarding the understandability of the information and ways to improve information presentation. We provided participants with a binder that included 8 to14 sample handbook pages. After participants reviewed each sample handbook page a trained interviewer asked six open-ended questions: 1) "Please tell me what you think the information on this page means," 2) "What does (fill in topic name) mean to you?" 3) "We're not sure if these are the best words to use, if you think there is a better way, we'd like to hear it," 4) "Is any part of this page unclear?" 5) "Do you have any other suggestions?" and, 6) "On a scale of $1-5$, with 1 being very hard to use and 5 being very easy to use, how would you score your ability to use this picture and the words to understand the information?" We audiorecorded and transcribed each interview. We reviewed transcriptions and made iterative changes to the handbook to address participants' comments.

Phase 2 cognitive interviews and assessment of comprehension During study Phase 2, we performed 36 additional cognitive interviews. As with Phase 1, we asked participants to provide qualitative feedback regarding the understandability and usability of information. In study Phase 2, we also assessed participants' "gist" comprehension $[27,28]$ of five key aspects of scientific evidence presented on each page, including whether they could understand: (1) the topic ("What issue are we talking about on this page?"), (2) the treatment 
modalities ("What treatments are being compared on this page?"), (3) the direction of differences in outcomes between RRTs being portrayed ("Which treatment is better?"), (4) the magnitude of difference in outcomes between RRTs ("How much better or worse is one treatment versus the other?"), and (5) the research quality of scientific studies to inform that aspect of the decision ("Does the page tell people how good the information is?").

We asked participants to view 7 to 9 different sample handbook pages displaying similar types of information (including information addressing five key aspects of scientific evidence: topic, treatment modalities being compared, direction of differences between treatments, magnitude of differences, and research quality). We assessed participants' gist comprehension of each key aspect on each page. Two independent investigators reviewed transcripts of each audio-recorded interview to assess participants' gist comprehension and scored participants' responses as correct or incorrect. A third research team member adjudicated any discrepancies among the two reviewers by also reviewing the transcripts.

For each key aspect of scientific evidence, we calculated the number of pages for which participants correctly demonstrated comprehension. For example, if a participant demonstrated correct comprehension of the treatments displayed on 7 of 9 pages, we assessed that participant as having correct comprehension of this element $78 \%$ of the time. We then summarized the total group's comprehension of each element by calculating the median (range) of all participants' percentages indicating correct comprehension of that element. We also assessed patient participants' demographic characteristics; health literacy (Rapid Estimate of Adult Literacy in Medicine) [29]; numeracy level (Risk Numeracy) [30]; cognitive function (Trails B) [31]; and knowledge and awareness of kidney disease [7].

\section{Handbook development stage 3: handbook screening and final edits}

Patients and family members who participated in the video screening (described above under "Video Development, Stage 3") also reviewed the handbook and provided opinions to the same open-ended questions.

\section{Results}

Feedback we received during each phase resulted in numerous iterative refinements of both the video and the handbook. We iteratively refined the video 17 times (11 script iterations in Stage 1, three initial video iterations in Stage 2, and three final film iterations in Stage 3). We iteratively refined the handbook 26 times (three iterations in Stage 1, 22 iterations in Stage 2, and one final iteration in Stage 3). Examples of preliminary handbook presentations, reflecting major iterative design approaches from Stages 1 and 2, are presented in Figure 2.

\section{Results: findings from mixed methods pilot study}

Of the 12 participants in pilot study Phase 1, 67\% were male, 92\% were African American, and 75\% had at most a high school degree or GED. The majority of participants were on hemodialysis $(n=9,75 \%)$, while the remaining participants were classified as pre-ESRD $(n=3$, $25 \%$ ). Of the 36 participants in Phase 2, 44\% were male, 83\% were African American, and 47\% had at most a high school degree or GED. Fifty-four percent of phase 2 participants were on hemodialysis, $33 \%$ were considered pre-ESRD, $29 \%$ on peritoneal dialysis, and $17 \%$ on home hemodialysis. Participants in both phases were diverse with respect to their knowledge of kidney disease, literacy, numeracy, and cognitive function (Table 2).

Qualitative feedback obtained during cognitive interviews (during Phase 1 and Phase 2) focused on three key areas: (1) difficulties identifying the multiple treatment types presented in the handbook, (2) the handbook containing an intimidating amount of complex scientific information, and (3) their desires to have numerical or quantitative information from scientific studies presented in a way that was clear and understandable. Through a total of 22 iterations (16 iterations in Phase 1 and six iterations in Phase 2) we addressed these concerns through numerous adjustments (including the use of color coding to consistently identify RRT options when discussed throughout the handbook, providing explanatory guides for how to read pages, eliminating the use of abbreviations, and supplementing graphical numerical presentations with text written at a $4^{\text {th }}$ to $6^{\text {th }}$ grade reading level) (Table 3 ).

During study Phase 2, we measured gist comprehension of materials among a total of 36 participants. Twenty-four (24) participants provided feedback on iteration 20 of the handbook and 12 participants provided feedback on iteration 21 of the handbook. Among all items viewed by participants, participants demonstrated median gist comprehension of $78 \%$ (range: $15 \%-100 \%$ ) in iteration 20 . Participants' median overall gist comprehension rose to a median of $91 \%$ (range: $9 \%-100 \%$ ) in iteration 21. Participants demonstrated greatest gist comprehension on aspects of pages reflecting the topic being discussed, the treatment types (modalities) being compared, and the direction of scientific findings discussing treatment differences (i.e., they could correctly identify one treatment was better than the other). Participants demonstrated less gist comprehension regarding the magnitude of treatment differences (i.e., they had difficulty understanding how much better one treatment was than another) and information about the research study quality. However, gist comprehension scores improved in these areas between iterations 20 and 21 (Table 4). 


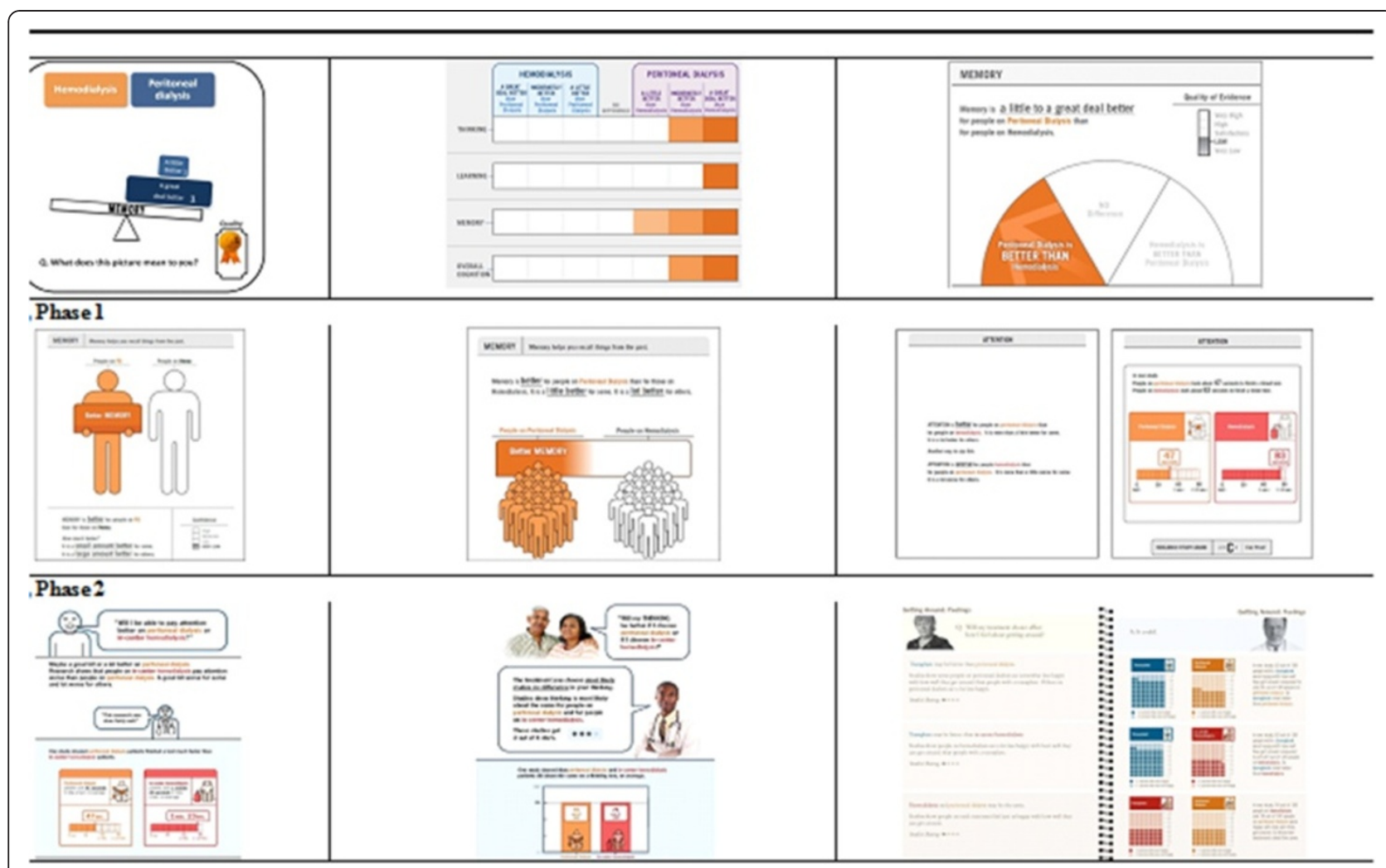

Figure 2 Representative sample iterations from stages 1 and 2 of the handbook development process.

\section{Results: feedback from decision Aid screening}

Five patients and seven family members participated in two different screening groups. Patient participants were $80 \%$ female, $60 \%$ African American, and 60\% had at least two years of college education. All family member participants were female, $71 \%$ were African American, and $43 \%$ had at least two years of college education.

Patients and family members provided mostly positive feedback after screening both the video and handbook. (Table 5) Participants often commented that they liked the organization of the video and the breadth of topics it covered. Participants also commented on the complementary nature of the two materials. Screening group participants constructively criticized the large amount of information presented in the handbook. To address this concern, we created a mini-book entitled, "All of the Facts," to accompany the handbook, which provides readers with a brief summary of key information presented in the longer handbook.

\section{Results: final decision Aid}

The final decision aid consists of a 50-minute video and a comprehensive, 159-page handbook accompanied by a 14-page mini-book ("All of the Facts") which summarizes the key information in the handbook. Together, the video and handbook satisfied $92 \%$ of all quality criteria outlined in the three subject areas designated by IPDAS (satisfied $96 \%$ or 22 of 23 content items, $87 \%$ or 20 of 23 development process items, and $100 \%$ or 6 of 6 effectiveness items) (Additional file 1).

The video provides testimonials from minority and non-minority (male and female) patients, their family members, and health care professionals (physicians and social workers) about "concerns" patients and their families might have which could influence their RRT selection decisions. These "concerns" correspond to the seven key content areas patients and their families identified as important to include in the decision aid during our foundational research studies. Patients and family members receiving different RRTs share subjective testimonials describing their positive and negative experiences with these "concerns" in the video. Health care providers discuss additional information regarding "concerns" to balance patient and family views and to contribute additional information.

The handbook provides evidence-based information regarding risks and benefits of different treatment options of peritoneal dialysis, in-center hemodialysis, home hemodialysis, kidney transplant, and conservative management (treatment with no transplant or dialysis) as they pertain to these same patient concerns. The introduction includes a section that defines kidney disease ("What Is 
Table 2 Participant characteristics for handbook development Stage 2 (Phases 1 and 2)

\begin{tabular}{|c|c|c|c|}
\hline \multirow{2}{*}{$\begin{array}{l}\text { Patient } \\
\text { characteristics, } \\
\mathrm{n}(\%)\end{array}$} & $\begin{array}{l}\text { All participants } \\
\text { (Phases } 1 \text { \& 2) }\end{array}$ & $\begin{array}{c}\text { Phase } 1 \\
\text { participants }\end{array}$ & $\begin{array}{c}\text { Phase } 2 \\
\text { participants }\end{array}$ \\
\hline & $(n=48)$ & $(n=12)$ & $(n=36)$ \\
\hline \multicolumn{4}{|l|}{ Age } \\
\hline Mean [Range] & 59 [33-85] & $58[46-71]$ & 60 [33-85] \\
\hline \multicolumn{4}{|l|}{ Gender } \\
\hline Male & 24 [50\%] & 8 [67\%] & 16 [44\%] \\
\hline \multicolumn{4}{|l|}{ Race/Ethnicity } \\
\hline African American & $41[85 \%]$ & 11 [92\%] & 30 [83\%] \\
\hline $\begin{array}{l}\text { non-African } \\
\text { American }\end{array}$ & 7 [15\%] & $1[8 \%]$ & 6 [17\%] \\
\hline \multicolumn{4}{|l|}{ Education } \\
\hline $\begin{array}{l}\text { Less than a high } \\
\text { school degree }\end{array}$ & 9 [19\%] & 4 [33\%] & 5 [14\%] \\
\hline $\begin{array}{l}\text { High school } \\
\text { degree/GED }\end{array}$ & 17 [35\%] & $5[42 \%]$ & 12 [33\%] \\
\hline Some college & 14 [29\%] & 3 [25\%] & 11 [31\%] \\
\hline Bachelor's degree & 6 [13\%] & 0 [0\%] & $6[17 \%]$ \\
\hline $\begin{array}{l}\text { Graduate or } \\
\text { professional school }\end{array}$ & $2[4 \%]$ & 0 [0\%] & $2[5 \%]$ \\
\hline
\end{tabular}

\section{Treatment Group}

\begin{tabular}{lccc}
\hline Pre-ESRD & $15[31 \%]$ & $3[25 \%]$ & $12[33 \%]$ \\
\hline Hemodialysis & $22[46 \%]$ & $9[75 \%]$ & $13[54 \%]$ \\
\hline Home Hemodialysis & $4[8 \%]$ & - & $4[17 \%]$ \\
\hline Peritoneal Dialysis & $7[15 \%]$ & - & $7[29 \%]$ \\
\hline
\end{tabular}

\section{Knowledge of}

Kidney Disease ${ }^{\S}$

\begin{tabular}{|c|c|c|c|}
\hline $\begin{array}{l}\text { Extensive } \\
\text { knowledge }\end{array}$ & 4 [8\%] & 1 [8\%] & $3[8 \%]$ \\
\hline $\begin{array}{l}\text { A great deal of } \\
\text { knowledge }\end{array}$ & 20 [42\%] & 4 [33\%] & 16 [44\%] \\
\hline Some knowledge & 18 [38\%] & 7 [59\%] & 11 [31\%] \\
\hline $\begin{array}{l}\text { Limited to no } \\
\text { knowledge }\end{array}$ & 5 [10\%] & 0 [0\%] & 5 [14\%] \\
\hline Don't know & 1 [2\%] & 0 [0\%] & 1 [3\%] \\
\hline \multicolumn{4}{|l|}{ Literacy } \\
\hline $\begin{array}{l}3^{\text {rd }} \text { grade and } \\
\text { below }\end{array}$ & 5 [10\%] & $1[8 \%]$ & 5 [14\%] \\
\hline 4th to $6^{\text {th }}$ grade & $4[8 \%]$ & 2 [17\%] & 2 [5\%] \\
\hline $7^{\text {th }}$ to $8^{\text {th }}$ grade & 14 [29\%] & 6 [50\%] & 8 [22\%] \\
\hline $\begin{array}{l}9^{\text {th }} \text { grade and } \\
\text { above }\end{array}$ & 25 [52\%] & 3 [25\%] & 22 [61\%] \\
\hline
\end{tabular}

above

\begin{tabular}{lccc}
\hline Numeracy & & & \\
\hline Risk numerate $^{\epsilon}$ & $14[30 \%]$ & $3[25 \%]$ & $11[31 \%]$ \\
\hline Cognition $^{*}$ & & & \\
\hline $\begin{array}{l}\text { Cognitive } \\
\text { impairment }\end{array}$ & $10[21 \%]$ & $3[25 \%]$ & $7[19 \%]$ \\
\hline
\end{tabular}

${ }^{\S}$ Based on self-report.

* Time of 273 seconds or longer indicates a cognitive deficiency, 2 participants missing data from Phase 2 .

${ }^{\epsilon}$ Considered risk numerate if 3 of 3 risk numeracy questions answered correctly, 1 participant missing from Phase 2 .
Kidney Disease?"), describes and color codes the different treatment options ("What are the Treatments?"), presents a value clarification exercise to help patients determine which treatment is best for them ("How Do I Choose a Treatment?"), and orients the reader to the page layout ("What is on Each Page?"). Subsequent sections of the handbook describe summaries of scientific studies relevant to each "concern." Handbook pages are 8.5 " by $11^{\prime \prime}$ and oriented toward a $4^{\text {th }}$ to $6^{\text {th }}$ grade reading level. The handbook delivers content on a double-page spread layout to appeal to diverse learning preferences: the lefthand page includes brief statements summarizing key messages from scientific studies while each right-hand page presents a more detailed summary of study findings and a graphical presentation of data (Figure 3).

\section{Discussion}

Patients need high quality decision aids to help guide them through the decision-making process about RRT selection. To our knowledge, rigorous and systematic approaches to developing decision aids for patients with CKD have not been previously undertaken. We developed our decision aid to accommodate patients with varying literacy, numeracy, and cognitive needs. The final decision aid achieved the vast majority of IPDAS criteria for engaging patients in informed decision-making. Our refinement process incorporated 11 video script iterations and 26 handbook iterations, reflecting the extensive effort we undertook to develop materials that addressed patients' self-reported informational needs. Initial screening of our decision aid by patients and their families indicates that these materials are likely to be well received. Pilot testing in our mixed-methods study suggested patients found the final handbook understandable. However, further testing is still needed to determine how effective or useful the decision aid is for ESRD patients' treatment decisions.

Our development process and findings highlight some of the challenges of developing comprehensive materials for a diverse population that address the positive and negative features of various RRT options. First, we based our content on rigorous foundational studies (20 focus groups and systematic literature reviews), which required substantial time and effort to conduct. Translating our findings from these studies to inform decision aid development also proved challenging as we sought to address multiple concerns identified by patients and invested additional significant time and effort performing the mixed-methods pilot study to identify ways to convey scientific information in a way that can be easily interpreted by the vast majority of patients. Further, factors such as the layout of information and the inclusion of figures are known to be potential sources of bias in decision making. For instance, the final handbook (150 pages) 
Table 3 Qualitative feedback from handbook development Stage 2 (Phases 1 and 2)

\begin{tabular}{|c|c|c|c|}
\hline Patient concerns & Representative quotes & $\begin{array}{l}\text { Specific challenges } \\
\text { encountered }\end{array}$ & Solutions \\
\hline \multirow[t]{4}{*}{$\begin{array}{l}\text { Patients did not know } \\
\text { their treatment options }\end{array}$} & \multirow{4}{*}{$\begin{array}{l}\text { "First, can you explain the two treatments? } \\
\text { What is the difference between those two } \\
\text { treatments?" }\end{array}$} & \multirow[t]{2}{*}{$\begin{array}{l}\text { - Defining patients' various } \\
\text { treatment options }\end{array}$} & $\begin{array}{l}\text { - Added a treatment definition page ("What } \\
\text { are the Treatments?") }\end{array}$ \\
\hline & & & $\begin{array}{l}\text { - Replaced all abbreviations with actual } \\
\text { treatment names }\end{array}$ \\
\hline & & \multirow{2}{*}{$\begin{array}{l}\text { - Making complex medical } \\
\text { terminology memorable }\end{array}$} & - Color-coded each treatment option \\
\hline & & & - Associated each treatment with its own icon \\
\hline \multirow[t]{6}{*}{$\begin{array}{l}\text { Intimidating amount of } \\
\text { complex information }\end{array}$} & \multirow{6}{*}{$\begin{array}{l}\text { "And I just feel like this is so much } \\
\text { information that's written that is not } \\
\text { going to be taken in." }\end{array}$} & \multirow[t]{3}{*}{$\begin{array}{l}\text { - Translating research } \\
\text { evidence into plain language }\end{array}$} & $\begin{array}{l}\text { - Developed a question and answer format in } \\
\text { plain language }\end{array}$ \\
\hline & & & $\begin{array}{l}\text { - Revised the language in the to achieve a } \\
\text { fourth grade reading level }\end{array}$ \\
\hline & & & $\begin{array}{l}\text { - Created a new section ("What is on Each } \\
\text { Page?") to introduce and define research } \\
\text { quality }\end{array}$ \\
\hline & & \multirow[t]{2}{*}{$\begin{array}{l}\text { - Communicating research } \\
\text { quality }\end{array}$} & $\begin{array}{l}\text { - Used pictures of "real" doctors and patients } \\
\text { diverse in age, sex, and gender }\end{array}$ \\
\hline & & & $\begin{array}{l}\text { - Placed tabs throughout the handbook to } \\
\text { divide it into smaller sections }\end{array}$ \\
\hline & & $\begin{array}{l}\text { - Making the handbook user- } \\
\text { friendly }\end{array}$ & $\begin{array}{l}\text { - Added an interactive value clarification } \\
\text { exercise ("How Do I Choose a Treatment?") }\end{array}$ \\
\hline \multirow{5}{*}{$\begin{array}{l}\text { Understanding numerical } \\
\text { information or statistical } \\
\text { concepts }\end{array}$} & \multirow[t]{5}{*}{$\begin{array}{l}\text { "I don't want these chances or things... it's } \\
\text { real confusing. I want to know the facts." }\end{array}$} & \multirow[t]{3}{*}{$\begin{array}{l}\text { - Presenting graphical } \\
\text { illustrations of data }\end{array}$} & $\begin{array}{l}\text { - Used graphical presentations patients } \\
\text { responded to most positively }\end{array}$ \\
\hline & & & $\begin{array}{l}\text { - Supplemented graphical presentations with } \\
\text { text to reiterate the intended message }\end{array}$ \\
\hline & & & $\begin{array}{l}\text { - Adopted a double page spread format to } \\
\text { appeal to a diverse group of readers }\end{array}$ \\
\hline & & $\begin{array}{l}\text { - Using both positive and } \\
\text { negative framing of statistical } \\
\text { information }\end{array}$ & $\begin{array}{l}\text { - Used an example study to anchor each } \\
\text { head-to-head treatment comparison }\end{array}$ \\
\hline & & - Explaining effect size & $\begin{array}{l}\text { - Modified effect size terminology from a } \\
\text { "small/medium/large amount" to "a little/ } \\
\text { somewhat/ a lot better" }\end{array}$ \\
\hline
\end{tabular}

and video (50 minutes) were lengthy. Although we did create a shorter "All the Facts" 14-page handbook in response to participants' comments during the screening sessions, we did not formally compare how participants viewed this distilled version of information compared to the complete handbook and video. Further testing will help clarify the optimum format for information. We are currently studying these materials in a randomized controlled trial to examine their influence on treatment decisions in African Americans [32], and we are designing additional studies to help further refine the decision aid.

Incorporating subjective testimonials about treatment could introduce bias as patients may identify with video participants rather than synthesize information on preference sensitive topics. [33-35] Nonetheless, treatments for ESRD are quite complex, requiring many practical considerations that significantly alter patients' daily lives. We therefore felt it was very important to show viewers examples of patients and families undergoing these treatments. For instance, our video shows a patient who receives home hemodialysis inserting a needle into his dialysis fistula. It shows another patient receiving hemodialysis in a treatment unit, and yet another patient administering peritoneal dialysis in her home with help from her spouse. The video depicts patients storing boxes of treatment supplies, handling medications, and

\section{Table 4 Median percentage ${ }^{* *}$ of times participants correctly comprehended key aspects of scientific evidence during pilot testing (handbook development Stage 2, Phase 2)}

\begin{tabular}{lccc}
\hline $\begin{array}{l}\text { Key aspects of } \\
\text { scientific evidence }\end{array}$ & Iteration 20 & & Iteration 21 \\
\cline { 2 - 2 } & $\mathbf{( n = 2 4 )}$ & & $\mathbf{( n = 1 2 )}$ \\
\hline Topic & $100 \%[22 \%-100 \%]$ & & $100 \%[0 \%-100 \%]$ \\
\hline Treatment Modality & $100 \%[33 \%-100 \%]$ & & $100 \%[29 \%-100 \%]$ \\
\hline Direction of Difference & $89 \%[22 \%-100 \%]$ & & $86 \%[14 \%-100 \%]$ \\
\hline Magnitude of Difference & $71 \%[0 \%-100 \%]$ & & $100 \%[0 \%-100 \%]$ \\
\hline Research Quality & $56 \%[0 \%-100 \%]$ & & $100 \%[0 \%-100 \%]$ \\
\hline Total: All Items & $78 \%[16 \%-100 \%]$ & & $91 \%[9 \%-100 \%]$ \\
\hline
\end{tabular}

*Correct identification of five key items shown as a median percentage. followed by the respective range.

**Ranges in the table represent [minimum-maximum] values. 
Table 5 Positive and constructive feedback obtained from screening the decision aid

\begin{tabular}{|c|c|c|c|c|}
\hline \multirow[t]{2}{*}{ Reactions } & \multicolumn{2}{|c|}{ Video } & \multicolumn{2}{|c|}{ Handbook } \\
\hline & Positive feedback & Constructive feedback & Positive feedback & Constructive feedback \\
\hline $\begin{array}{l}\text { Overall } \\
\text { Impression }\end{array}$ & $\begin{array}{l}\text { "... if it was something like that } \\
\text { available... when I started } \\
\text { dialysis it would have really } \\
\text { been welcome because } \\
\text { information was } \\
\text { scattered. . .And this, I like the } \\
\text { way it's organized, the way it's } \\
\text { broken down. . I think it's } \\
\text { touched just about on } \\
\text { everything that your initial } \\
\text { concerns would be." }\end{array}$ & $\begin{array}{l}\text { "What I did have an issue with } \\
\text { was the sequence of, I liked the } \\
\text { way everything was broken } \\
\text { down but I think it should have } \\
\text { been sequenced differently } \\
\text { starting with dialysis at the } \\
\text { center, because they said that } \\
\text { was what's most frequently } \\
\text { done, most frequently used." }\end{array}$ & $\begin{array}{l}\text { "I really do love this book. It } \\
\text { does give a whole lot of } \\
\text { information for someone who's } \\
\text { just starting out. You know, } \\
\text { they really need all of the } \\
\text { information they can-that they } \\
\text { can get. And I love the fact that } \\
\text { they would have a DVD to go } \\
\text { along with it." }\end{array}$ & $\begin{array}{l}\text { "A lot of times if a person is just } \\
\text { starting dialysis, you know, you } \\
\text { got the sluggishness in your } \\
\text { brain, your memory, and your } \\
\text { attention. And it might be a } \\
\text { little hard to focus on this as } \\
\text { opposed to seeing a film, } \\
\text { hearing people's testimonies, } \\
\text { you know, I think that would } \\
\text { settle a little better than, you } \\
\text { know, trying to absorb all of } \\
\text { this." }\end{array}$ \\
\hline Length & $\begin{array}{l}\text { "But I didn't mind the length of } \\
\text { it because it gave, you know, } \\
\text { information that you need to } \\
\text { know." }\end{array}$ & $\begin{array}{l}\text { "I thought it was too long. But } \\
\text { as it went on we could see } \\
\text { how important it was for it to } \\
\text { be that long and I think if I was } \\
\text { in that situation, it might not } \\
\text { have been that long but since } \\
\text { it wasn't my issue, too long." }\end{array}$ & $\begin{array}{l}\text { "When I first saw it, it felt } \\
\text { overwhelming but it was } \\
\text { broken down so well that I can } \\
\text { just go to the parts that I think } \\
\text { are relevant to myself or that I } \\
\text { want to see that day. . . it's } \\
\text { separated so well that I can just } \\
\text { go and look at it." }\end{array}$ & $\begin{array}{l}\text { "I mean, the inside of it, the } \\
\text { content is good. I like the } \\
\text { graphics in it and the } \\
\text { charts. . . but I guess if it was } \\
\text { some kind of way you could } \\
\text { kind of condense it because } \\
\text { they're probably already getting } \\
\text { a whole lot of other information } \\
\text { at the same time to have to } \\
\text { carry a big book." }\end{array}$ \\
\hline $\begin{array}{l}\text { Amount of } \\
\text { Information }\end{array}$ & $\begin{array}{l}\text { "I think it's very informative and } \\
\text { has just the right amount of } \\
\text { information." }\end{array}$ & $\begin{array}{l}\text { Constructive feedback not } \\
\text { available }\end{array}$ & $\begin{array}{l}\text { "I think this is a terrific } \\
\text { reinforcing publication plus } \\
\text { when you're watching a film } \\
\text { you can only remember so } \\
\text { much whereas you're going to } \\
\text { go back here and you're going } \\
\text { to see all of it in the different } \\
\text { forms... Reading and writing } \\
\text { solidify your thinking. . .l like it." }\end{array}$ & $\begin{array}{l}\text { "It could be very daunting just } \\
\text { even looking at it. But if you } \\
\text { have a video hopefully it will } \\
\text { pique your interest enough to } \\
\text { be able to go to the individual } \\
\text { area that you're concerned with } \\
\text { and get that information that } \\
\text { you need." }\end{array}$ \\
\hline $\begin{array}{l}\text { Easy to } \\
\text { Understand }\end{array}$ & $\begin{array}{l}\text { "I did learn a lot of information } \\
\text { from watching the movie. Even } \\
\text { having some relatives that had } \\
\text { kidney issues, this still provided } \\
\text { more information." }\end{array}$ & $\begin{array}{l}\text { Constructive feedback not } \\
\text { available }\end{array}$ & $\begin{array}{l}\text { "It's doesn't go to a junior high } \\
\text { school level so that means that } \\
\text { everybody can understand it. } \\
\text { So yeah I think it's clear." }\end{array}$ & $\begin{array}{l}\text { "The spoken word, a lot of } \\
\text { times, is much easier. I think the } \\
\text { combination is a great vehicle, I } \\
\text { do. But I think with this, you } \\
\text { know, that's one of the things } \\
\text { that I'd be concerned about. } \\
\text { 'Cause someone with a fifth } \\
\text { grade reading level wouldn't } \\
\text { really be able to understand } \\
\text { everything." }\end{array}$ \\
\hline $\begin{array}{l}\text { Balanced } \\
\text { Presentation } \\
\text { of Treatment } \\
\text { Options }\end{array}$ & $\begin{array}{l}\text { "I don't think they leaned } \\
\text { anywhere. In fact, they kept } \\
\text { saying basically it was your } \\
\text { options to select or decide } \\
\text { which way you want to go and } \\
\text { you even had an option to } \\
\text { rescind that and go in another } \\
\text { direction." }\end{array}$ & $\begin{array}{l}\text { Constructive feedback not } \\
\text { available }\end{array}$ & $\begin{array}{l}\text { "Yeah it's pretty well balanced } \\
\text { because it has the section for } \\
\text { each treatment, you know, } \\
\text { each mode in there so it's } \\
\text { balanced." }\end{array}$ & $\begin{array}{l}\text { Constructive feedback not } \\
\text { available }\end{array}$ \\
\hline $\begin{array}{l}\text { Areas of } \\
\text { Improvement }\end{array}$ & Not applicable & $\begin{array}{l}\text { "I think the one improvement } \\
\text { that I would suggest is that } \\
\text { [they put] a little bit more } \\
\text { emphasis in each type of } \\
\text { treatment about the emotional } \\
\text { impact on not just you but also } \\
\text { your family and your support } \\
\text { system." }\end{array}$ & Not applicable & $\begin{array}{l}\text { "I think the best part and most } \\
\text { useful part for most of the } \\
\text { population is the all the facts } \\
\text { part. It's nice how they've } \\
\text { compared the transplant, which } \\
\text { is the ideal, to the other } \\
\text { treatments. It might be helpful } \\
\text { if there were a foldout where all } \\
\text { the treatments were laid out } \\
\text { like this to just read across." }\end{array}$ \\
\hline
\end{tabular}




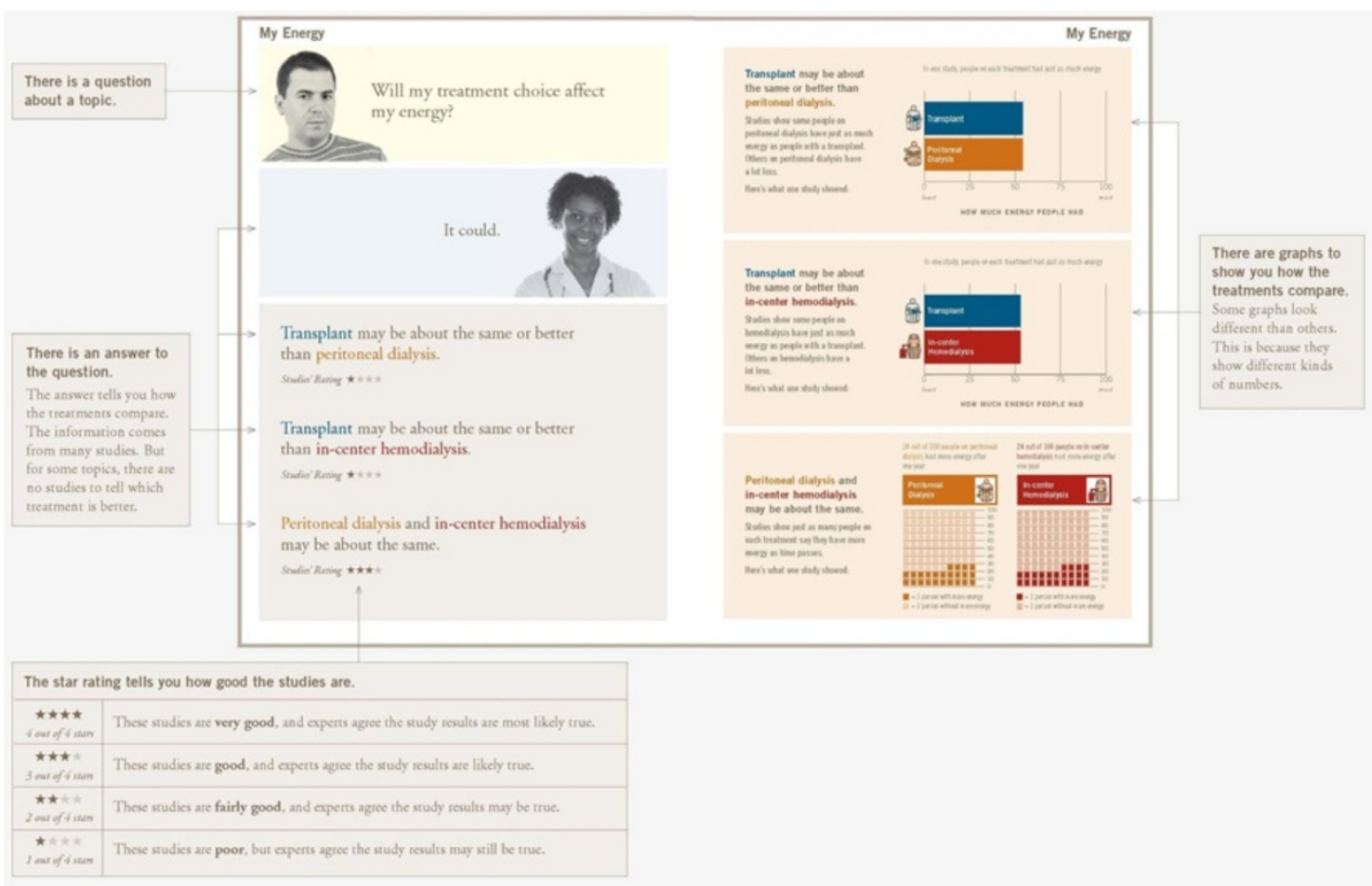

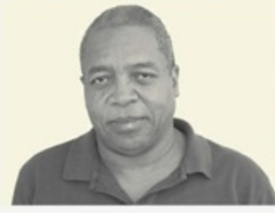

Will my treatment choice affect my chances of living for five years?

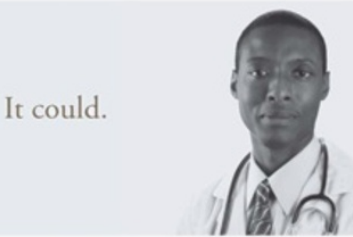

Transplant from a living donor may be better than the other treatments.

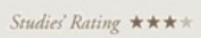

Studies show 82 out of 100 people who got a transplant from a living donor were alive at the end of five years. 18 out of 100 people who got a transplant from a living donor died by the end of five years.

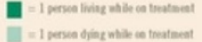

Studies show 73 out of 100 people who got a transplant from a deceased donor were alive at the end of five years. 27 out of 100 people who got a transplant from a deceased donor died by the end of five years.

a

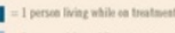

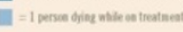

Studies show 41 out of 100 people on peritoneal dialysis were alive at the end of five years.

59 out of 100 people on peritoneal dialysis died by the end of five years.

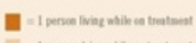

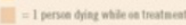

Studies show 37 out of 100 people on hemodialysis were alive at the end of five years.

63 out of 100 people on hemodialysis died by the end of five years.

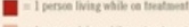

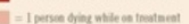
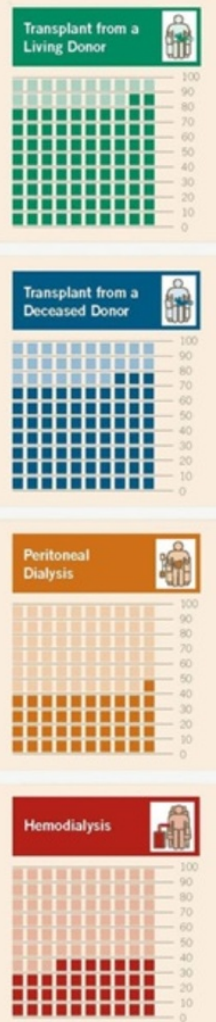

Figure 3 Sample pages from final handbook. 
traveling to the dialysis treatment facility. Without direct visualization, many patients considering these treatments may not fully comprehend the significant differences between therapies. Future studies will be needed to assess whether viewers of our video felt compelled to choose a treatment because of their subjective identification with video participants.

Some additional limitations of our process are important to consider. Although our team comprised experts from multiple disciplines, it did not include a decision scientist, which may have influenced our development approach. We did, however, refer to the decision sciences literature extensively as well as the IPDAS criteria throughout the development process [19,25-28,36-40]. We also developed our decision aid with input from a largely minority (African American) population of patients with kidney disease living in the Baltimore, MD metropolitan area. It is possible patients with different characteristics could have different viewpoints about RRT which might have altered our development process. Further, we developed our decision aid for English-speaking patients. Materials may require significant adaptation to accommodate reading and cultural needs of non-English speakers.

\section{Conclusion}

We developed a decision aid to help patients with kidney disease and their families make informed decisions about RRT selections aligned with their values. While our development process helped to ensure completeness and readability of our decision aid, its effectiveness on aiding patients' treatment decisions warrants further study.

\section{Additional file}

Additional file 1: IPDAS criteria met by video and handbook decision aid.

\section{Abbreviations}

CKD: Chronic kidney disease; ESRD: End-stage renal disease; RRT: Renal replacement therapy; IPDAS: International patient decision aid standards.

\section{Competing interests}

The authors declare that they have no competing interests.

\section{Authors' contributions}

JA made substantial contributions to conception and design, acquisition of data, analysis and interpretation of data, was involved in drafting the manuscript or revising it critically for important intellectual content, and gave final approval of the version to be published. PA made substantial contributions to conception and design, acquisition of data, analysis and interpretation of data and gave final approval of the version to be published. PE made substantial contributions to conception and design, acquisition of data, analysis and interpretation of data and gave final approval of the version to be published. LLB made substantial contributions to conception and design, acquisition of data, analysis and interpretation of data and gave final approval of the version to be published. ND made substantial contributions to conception and design, analysis and interpretation of data, was involved in drafting the manuscript or revising it critically for important intellectual content, and gave final approval of the version to be published. RG made substantial contributions to conception and design, analysis and interpretation of data and gave final approval of the version to be published. DC made substantial contributions to conception and design, analysis and interpretation of data and gave final approval of the version to be published. NP made substantial contributions to conception and design, acquisition of data, analysis and interpretation of data and gave final approval of the version to be published. HR made substantial contributions to conception and design, acquisition of data, analysis and interpretation of data and gave final approval of the version to be published. LEB led the conception and design, acquisition of data, analysis and interpretation of data, and was involved in drafting the manuscript as well as revising it critically for important intellectual content. LEB also gave final approval of the version to be published. All authors read and approved the final manuscript.

\section{Acknowledgments}

Support came from an Investigator Initiated Grant from the Foundation for Informed Medical Decisions (Drs. Boulware and Powe; Ms. Ephraim), Grant \#R01DK079682 from the National Institute of Diabetes and Digestive and Kidney Diseases (All Authors), Grant \#K23DK070757 from the National Center for Minority Health and Health Disparities and the National Institute of Diabetes and Digestive and Kidney Diseases (Dr. Boulware), Grant \#K240502643 from the National Institute of Diabetes and Digestive and Kidney Diseases (Dr. Powe), A grant from the Harold Amos Faculty Development Program of the Robert Wood Johnson Foundation(Dr. Crews), Grant \# 5KL2RR025006 from the National Center for Research Resources (NCRR), a component of the National Institutes of Health $(\mathrm{NIH})$ and the $\mathrm{NIH}$ Roadmap for Medical Research (Dr. Greer), and Grant \# 3R01DK079682-03S1 from the National Institute of Diabetes and Digestive and Kidney Diseases (Dr. Greer)

\section{Author details}

${ }^{1}$ Welch Center for Prevention, Epidemiology and Clinical Research, Johns Hopkins Medical Institutions, Baltimore, Maryland, USA. ²Division of General Internal Medicine, Johns Hopkins University School of Medicine, Baltimore, Maryland, USA. ${ }^{3}$ Department of Epidemiology, Johns Hopkins Bloomberg School of Public Health, Baltimore, USA. ${ }^{4}$ Division of Nephrology, Johns Hopkins Medical Institutions, Baltimore, Maryland, USA. ${ }^{5}$ Department of Medicine, University of California San Francisco and San Francisco General Hospital, San Francisco, California, USA.

Received: 24 August 2012 Accepted: 27 November 2012 Published: 1 December 2012

\section{References}

1. Bass EB, Wills S, Fink NE, Jenckes MW, Sadler JH, Levey AS, Meyer K, Powe NR: CHOICE study: How strong are patients' preferences in choices between dialysis modalities and doses? Am J Kidney Dis 2004, 44(4):695-705

2. Morton RL, Tong A, Howard K, Snelling P, Webster AC: The views of patients and carers in treatment decision making for chronic kidney disease: systematic review and thematic synthesis of qualitative studies. BMJ 2010, 340:c112.

3. Ormandy P: Information topics important to chronic kidney disease patients: a systematic review. J Ren Care 2008, 34(1):19-27.

4. Oreopoulous DG, Thodis E, Passadakis P, Vargemezis V: Home dialysis as a first option: a new paradigm. Int Urol Nephrol 2009, 41:595-605.

5. Sheu J, Ephraim PL, Powe NR, Rabb H, Senga M, Evans KE, Jaar BG, Crews DC, Greer RC, Boulware LE: African American and non-African American patients' and families' decision making about renal replacement therapies. Qual Health Res 2012, 22(7):997-1006.

6. Cavanaugh KL, Wingard RL, Hakim RM, Elasy TA, Ikizler TA: Patient dialysis knowledge is associated with permanent arteriovenous access use in chronic hemodialysis. Clin J Am Soc Nephrol: CJASN 2009, 4(5):950-956.

7. Finkelstein FO, Story K, Firanek C, Barre P, Takano T, Soroka S, Mujais S, Rodd K, Mendelssohn: Perceived knowledge among patients cared for by nephrologists about chronic kidney disease and end-stage renal disease therapies. Kidney Int 2008, 74(9):1178-1184.

8. Mehrotra R, Marsh D, Vonesh E, Peters V, Nissenson A: Patient education and access of ESRD patients to renal replacement therapies beyond incenter hemodialysis. Kidney Int 2005, 68(1):378-390. 
9. Ayanian JZ, Cleary PD, Weissman JS, Epstein AM: The effect of patients' preferences on racial differences in access to renal transplantation. N Engl J Med 1999, 341(22):1661-1669.

10. Stehman-Breen CO, Sherrard DJ, Gillen D, Caps M: Determinants of type and timing of initial permanent hemodialysis vascular access. Kidney Int 2000, 57(2):639-645.

11. Grubbs V, Gregorich SE, Perez-Stable EJ, Hsu CY: Health literacy and access to kidney transplantation. Clin J Am Soc Nephrol 2009, 4(1):195-200.

12. Lenz O, Sadhu S, Fornoni A, Asif A: Overutilization of central venous catheters in incident hemodialysis patients: reasons and potential resolution strategies. Semin Dial 2006, 19(6):543-550.

13. Lee T, Barker J, Allon M: Associations with predialysis vascular access management. Am J Kidney Dis: the official journal of the National Kidney Foundation. 2004, 43(6):1008-1013.

14. Abecassis M, Bartlett $S T$, Collins AJ, Davis CL, Delmonico FL, Friedewald JJ, Hays R, Howard A, Jones E, Leichtman AB, Merion RM, Metzger RA, Pradel F, Schweitzer EJ, Velez RL, Gaston RS: Kidney transplantation as primary therapy for end-stage renal disease: A National Kidney Foundation/ Kidney Disease Outcomes Quality Initiative (NKF/KDOQITM) conference. Clin J Am Soc Nephrol 2008, 3:471.

15. Wright JA, Wallston KA, Elasy TA, Ikizler TA, Cavanaugh KL: Development and results of a kidney disease knowledge survey given to patients with CKD. Am J Kidney Dis: the official journal of the National Kidney Foundation. 2011, 57(3):387-395

16. Cavanaugh K, Huizinga MM, Wallston KA, Gebretsadik T, Shintani A, Davis D, Gregory RP, Fuchs L, Malone R, Cherrington A, Pignone M, DeWalt DA, Elasy $T A$, Rothman RL: Association of numeracy and diabetes control. Ann Intern Med 2008, 148(10):737-746.

17. Pandit AU, Tang JW, Bailey SC, Davis TC, Bocchini MV, Persell SD, Federman AD, Wolf MS: Education, literacy, and health: mediating effects on hypertension knowledge and control. Patient Educ Couns 2009, 75(3):381-385.

18. Osborn CY, Cavanaugh K, Wallston KA, White RO, Rothman RL: Diabetes numeracy mediates the association between African American race and poor glycemic control. Diabetes Care 2009, 32(9):1614-1619.

19. Elwyn G, O'Connor A, Stacey D, Volk R, Edwards A, Coulter A, Thomson R, Barrratt A, Barry M, Berstein S, Butow P, Clarke A, Entwistle V, FeldmanStewart D, Holmes-Rovner M, Llewellyn-Thomas H, Moumijd N, Mulley A, Ruland C, Sepucha K, Sykes A, Whelan T: Developing a quality criteria framework for patient decision aids: online international Delphi consensus process. BMJ 2006, 333(7565):417.

20. Bass EB, Jenckes MW, Fink NE, WU AW, Sadler JH, Meyer KB, Levey A, Power NR: Use of focus groups to identify concerns about dialysis: choice study. Med Decis Making. 1999, 19:287-295.

21. Auguste $P$, Greer R, Ephraim P, Sheu J, Lamprea J, Olufade T, Purnell T, Powe NR, Rabb H, Jaar B, Boulware LE: Quality of evidence informing patients' choice of renal replacement modalty (RRM) [abstract]. J Am Soc Nephrol 2010, (21). Proceedings of the American Society of Nephrology Renal Week

22. Olufade T, Auguste $P$, Crews DC, Lamprea J, Purnell TS, Greer R, Ephraim P, Sheu J, Powe NR, Rabb H, Boulware LE: Comparison of sexual dysfunction between renal replacement therapies: a systematic review [abstract]. J Am Soc Neph 2011, 22:204A. Proceedings of the American Society of Nephrology Kidney Week.

23. Crews DC, Auguste P, Purnell TS, Greer R, Olufade T, Lamprea J, Sheu J, Ephraim P, Rabb H, Powe NR, Boulware LE: Comparison of cognitive function across ESRD treatment modalities: a systematic review [abstract]. J Am Soc Neph 2011, 22:256A. Proceedings of the American Society of Nephrology Kidney Week.

24. Purnell T, Auguste P, Crews DC, Lamprea J, Olufade T, Greer R, Ephraim P, Shue J, Powe NR, Rabb H, Boulware LE: Comparison of life participation outcomes between renal replacement therapy modalities: a systematic review [abstract]. J Am Soc Neph 2011, 22:734A. Proceedings of the American Society of Nephrology Kidney Week.

25. Spiegelhalter $D$, Pearson $M$, Short I: Visualizing uncertainty about the future. Science 2011, 333(6048):1393-1400

26. Glenton C, Santesso N, Rosenbaum S, Nilsen ES, Rader T, Ciapponi A, Dilkes $H$ : Presenting the results of Cochrane systematic reviews to a consumer audience: a qualitative study. Med Decis Making 2010, 30(5):566-577.

27. Hawley ST, Zikmund-Fisher B, Ubel P, Jancovic A, Lucas T, Fagerlin A: The impact of the format of graphical presentation on health-related knowledge and treatment choices. Patient Educ Couns 2008, 73(3):448-455.
28. Tait AR, Voepel-Lewis T, Zikmund-Fisher BJ, Fagerlin A: The effect of format on parents' understanding of the risks and benefits of clinical research: a comparison between text, tables, and graphics. J Health Commun 2010, 15(5):487-501

29. Murphy PW, Davis TC, Long SW, Jackson RH, Decker BC: Rapid estimate of adult literacy in medicine (REALM): a quick reading test for patients. J Read 1993, 37(2):124-130.

30. Fagerlin A, Zikmund-Fisher BJ, Ubel PA, Jankovic A, Derry HA, Smith DM: Measuring numeracy without a math test: development of the Subjective Numeracy Scale (SNS). Med Decis Making. 2007, 27:672-680.

31. Gaudino EA, Geisler MW, Squires NK: Construct validity in the trail making test: what makes part B harder? J Clin Exp Neuropsychol 1995, 17(4):529-535.

32. Ephraim PL, Powe NR, Rabb H, Ameling J, Auguste P, Lewis-Boyer L, Greer RC, Crews DC, Purnell TS, Jaar BG, DePasquale N, Boulware LE: The Providing Resources to Enhance African American Patients' Readiness to Make Decisions about Kidney Disease (PREPARED) Study: Protocol of a randomized controlled trial. BMC Nephrol 2012, In Press.

33. Ubel PA, Jepson C, Baron J: The inclusion of patient testimonials in decision aids: effects on treatment choices. Med Decis Making 2001, 21(1):60-68

34. Feldman-Stewart D, Brennenstuhl S, Mclssac K, Austoker J, Charvet A Hewitson P, Sepucha KR, Whelan T: A systematic review of information in decision aids. Health Expect 2007, 10(1):46-61. Review. PubMed PMID: 17324194

35. Winterbottom A, Bekker HL, Conner M, Mooney A: Does narrative information bias individual's decision making? A systematic review. Soc Sci Med 2008, 67:2079-2088.

36. Tversky A, Kahneman D: Rational choice and the framing of decisions, The journal of business. Vol. 59, No. 4, Part 2: the behavioral foundations of economic theory (Oct., 1986). Chicago: The University of Chicago Press; 1986: S251-S278.

37. Fagerlin A, Zikmund-Fisher BJ, Ubel PA: Helping patients decide: ten steps to better risk communication. J Natl Cancer Inst 2011, 103(19):1436-1443. Epub 2011 Sep 19. PubMed PMID: 21931068; PubMed Central PMCID: PMC3218625.

38. Fagerlin A, Ubel PA, Smith DM, Zikmund-Fisher BJ: Making numbers matter: present and future research in risk communication. Am J Health Behav 2007, 31(Suppl 1):S47-S56.

39. Zikmund-Fisher BJ, Fagerlin A, Ubel PA: A demonstration of "less can be more" in risk graphics. Med Decis Making 2010, 30(6):661-671. Epub 2010 Apr 7. PubMed PMID: 20375419

40. Lipkus IM: Numeric, verbal, and visual formats of conveying health risks: suggested best practices and future recommendations. Med Decis Making 2007, 27(5):696-713. Epub 2007 Sep 14. Review. PubMed PMID: 17873259.

\section{doi:10.1186/1472-6947-12-140}

Cite this article as: Ameling et al:: Development of a decision aid to inform patients' and families' renal replacement therapy selection decisions. BMC Medical Informatics and Decision Making 2012 12:140.

\section{Submit your next manuscript to BioMed Central and take full advantage of:}

- Convenient online submission

- Thorough peer review

- No space constraints or color figure charges

- Immediate publication on acceptance

- Inclusion in PubMed, CAS, Scopus and Google Scholar

- Research which is freely available for redistribution 